\title{
Effect of geniposide, a hypoglycemic glucoside, on hepatic regulating enzymes in diabetic mice induced by a high-fat diet and streptozotocin
}

\author{
Shao-yu WU*, Guang-fa WANG , Zhong-qiu LIU, Jin-jun RAO, Lin LÜ, Wei XU, Shu-guang WU*, Jia-jie ZHANG* \\ School of Pharmaceutical Sciences, Southern Medical University, Guangzhou 510515, China
}

\begin{abstract}
Aim: Hepatic glycogen phosphorylase (GP) and glucose-6-phosphatase (G6Pase) play an important role in the control of blood glucose homeostasis and are proposed to be potential targets for anti-diabetic drugs. Geniposide is an iridoid glucoside extracted from Gardenia jasminoides Ellis fruits and has been reported to have a hypoglycemic effect. However, little is known about the biochemical mechanisms by which geniposide regulates hepatic glucose-metabolizing enzymes. The present study investigates whether the hypoglycemic effect of geniposide is mediated by GP or G6Pase.

Methods: Type 2 diabetic mice, induced by a high-fat diet and streptozotocin injection, were treated with or without geniposide for 2 weeks. Blood glucose levels were monitored by a glucometer. Insulin concentrations were analyzed by the


hepatic GP and G6Pase were measured by glucose-6-phosphate dehydrogenase-coupled reaction. Real-time RT-PCR and Western blotting were used to determine the mRNA and protein levels of both enzymes.

Results: Geniposide (200 and $400 \mathrm{mg} / \mathrm{kg}$ ) significantly decreased the blood glucose, insulin and TG levels in diabetic mice in a dose-dependent manner. This compound also decreased the expression of GP and G6Pase at mRNA and immunoreactive protein levels, as well as enzyme activity.

Conclusion: Geniposide is an effective hypoglycemic agent in diabetic mice. The hypoglycemic effect of this compound may be mediated, at least in part, by inhibiting the GP and G6Pase activities.
\end{abstract}

Keywords: type 2 diabetes; geniposide; glycogen phosphorylase; glucose-6-phosphatase; hepatic glucose-regulating enzymes; hypoglycemic agents

Acta Pharmacologica Sinica (2009) 30: 202-208; doi: 10.1038/aps.2008.17; ublished online 5th January 2009

\section{Introduction}

Type 2 diabetes is a metabolic disease with elevated blood glucose production and impaired glucose clearance. The synthesis and degradation of glycogen in the liver are important mechanisms in the control of blood glucose homeostasis ${ }^{[1,2]}$. The inhibition of enzymes involved in glycogenolysis constitutes an alternative approach to suppressing hepatic glucose production and lowering blood glucose levels ${ }^{[3-5]}$. Hepatic glycogen phosphorylase (GP) and glucose-6-phosphatase (G6Pase) are two key enzymes in glycogenolysis. GP catalyzes the first step of the breakdown

\footnotetext{
\# These authors contributed equally to this paper.

* Correspondence to Dr Shu-guang WU and Dr Jia-jie ZHANG.

E-mail shuguang@smu.edu.cn; zhangij@smu.edu.cn

Received 2008-09-07 Accepted 2008-11-27
}

of glycogen to yield glucose-1-phosphate, whereas G6Pase catalyzes the final reaction in hepatic glucose production (Figure 1$)^{[6]}$. Both enzymes have been proposed as potential targets for antihyperglycemic drugs for type- 2 diabetes ${ }^{[5,7,8]}$.

Geniposide is an iridoid glucoside extracted from



Figure 1. Pathways of glycogen metabolism in the liver. GP catalyses the first step of the breakdown of glycogen to yield glucose-1phosphate, whereas G6Pase converted glucose-6-phosphate to glucose, which is then released into the blood. 
Gardenia jasminoides Ellis fruits, which have long been used in traditional Chinese medicine ${ }^{[9]}$. This compound has been shown to posses anti-diabetic ${ }^{[10]}$, anti-inflammatory ${ }^{[11]}$, detoxifying ${ }^{[12]}$, anti-oxidative ${ }^{[13]}$ and anti-angiogenic properties $^{[14]}$. The first report of its hypoglycemic activity in high sugar diet-induced diabetic mice was made in $1982^{[10]}$. Recent studies further confirmed the hypoglycemic effects of geniposide and genipin, an aglycone of the enzyme-hydrolytic geniposide ${ }^{[15,16]}$. The anti-diabetic property of genipin is related to the inhibition of uncoupling protein 2 (UCP2), a mitochondrial carrier proton $^{[15,16]}$. However, little is known about the biochemical mechanisms by which geniposide regulates hepatic glucose-metabolizing enzymes.

In the present study, we investigated the effects of geniposide on blood glucose, total cholesterol (TC), and triglyceride (TG), as well as the enzyme activities and expression of hepatic GP and G6Pase in mice with diabetes induced by a high-fat diet (HFD) and streptozotocin (STZ) (HFD-STZ diabetic mice).

\section{Materials and methods}

\section{Reagents}

Geniposide (98\%, Figure 2) was purchased from the National Institute for the Control of Pharmaceutical and Biological Products (Beijing, China). Streptozotocin (STZ) was purchased from Sigma (St Louis, MO, USA), TRIzol reagent from Invitrogen (Carlsbad, CA, USA), and M-MLV reverse transcriptase from Epicentre (Madison, Wisconsin, USA). Western blotting lysis buffer was from Kangchen Bio-tech Inc (Shanghai, China). The rabbit polyclonal anti-GP antibody (sc-66913) and the rabbit polyclonal anti-G6Pase antibody (sc-25840) were obtained from Santa Cruz (Santa Cruz, CA,

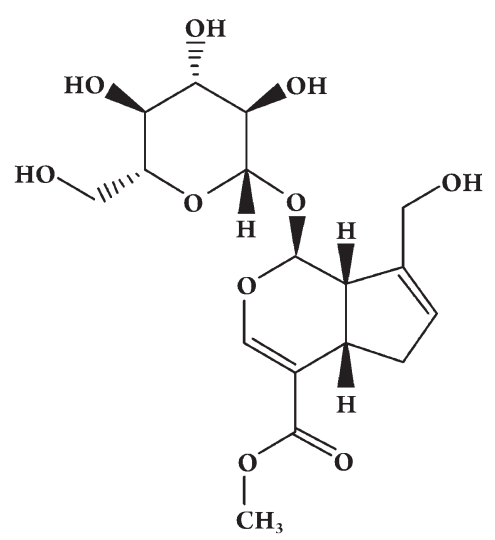

Figure 2. Structure of geniposide from Gardenia jasminoides Ellis fruits.
USA). Horseradish peroxidase-conjugated secondary antibody was from Kangchen Bio-tech Inc (Shanghai, China). Leuconostoc mesenteroides glucose-6-phosphate dehydrogenase (G6PD), phosphoglucomutase and adenosine monophosphate (AMP) were purchased from Sigma (St Louis, MO, USA). All other reagents were from Sigma (USA), except where specified.

\section{Induction of diabetic mice}

Male C57BL/6J mice from the Institute of Zoology, Southern Medical University (Guangzhou, China), were obtained at 3 weeks of age. The animals were housed in a temperature $\left(22 \pm 3{ }^{\circ} \mathrm{C}\right)$ and humidity $(50 \% \pm 20 \%)$ controlled room with a $12 \mathrm{~h}$ light/dark cycle. The mice were randomly divided into normal diet control and HFD groups. The control group received a diet containing $(w / w) 4.5 \%$ fat, $23 \%$ protein, $67.5 \%$ carbohydrates and $5 \%$ mixture of vitamins and mineral salts. The HFD group received a diet containing $(w / w) 35.5 \%$ fat, $20 \%$ protein, $39.5 \%$ carbohydrates and $5 \%$ mixture of vitamins and mineral salts ${ }^{[17,18]}$. The water and food were monitored daily to quantify food intake. After exposure to the respective diets for 3 weeks, the HFD group was injected with a single dose of STZ $(100 \mathrm{mg} / \mathrm{kg}$ body weight). Blood samples were collected through the tail vein and blood glucose levels were measured using a glucometer (Johnson \& Johnson LifeScan, California, USA). The mice with blood glucose levels between $10.0 \mathrm{mmol} / \mathrm{L}$ and 20.0 $\mathrm{mmol} / \mathrm{L}$ were selected for the present study.

\section{Treatment schedule}

At the third week after STZ injection, diabetic mice were randomly divided into 4 groups ( $n=10$ each), treated with geniposide $\left(100,200\right.$, and $\left.400 \mathrm{mg} \cdot \mathrm{kg}^{-1} \cdot \mathrm{d}^{-1}\right)$ or without geniposide. Body weights and blood glucose levels of the animals were measured weekly. At the second week after drug treatment, mice were euthanized and blood was collected into EDTA-coated tubes. Plasma was separated by centrifugation at $1000 \times \mathrm{g}$ for $10 \mathrm{~min}$. Plasma TC and TG were detected using Labassay ${ }^{\mathrm{TM}}$ kits (Wako, Saitama, Japan) according to the manufacturer's protocols. Plasma insulin was detected by an ELISA kit (Shibayagi, Shibakawa, Japan).

All of the procedures were approved by the Committee on Animal Research and Ethics of Southern Medical University.

\section{Liver tissue preparation for GP and G6Pase assay}

The whole liver was quickly removed from mice, and $100 \mathrm{mg}$ of wet hepatic tissue was placed into ice-cold 0.25 $\mathrm{mol} / \mathrm{L}$ sucrose solutions. The mixture was homogenized at 
$4{ }^{\circ} \mathrm{C}$ for $1 \mathrm{~min}$ and diluted to $2 \mathrm{~mL}$ per $100 \mathrm{mg}$ wet liver with the sucrose solution. The homogenate was centrifuged at $4{ }^{\circ} \mathrm{C} 12000 \times g$ for $30 \mathrm{~min}$. The supernatant fluid was collected and frozen for enzymatic assay ${ }^{[19-21]}$.

\section{Determination of G6Pase activity}

G6Pase activity was determined through the use of the glucose-6-phosphate dehydrogenase (G6PD)coupled reaction ${ }^{[20-22]}$. G6Pase catalyzes the conversion of glucose-6-phosphate to glucose, which is further oxidized to $\beta$-D-gluconolactone by G6PD in the presence of nicotinamide adenine dinucleotide $\left(\mathrm{NAD}^{+}\right)$. The change in the absorbance at $340 \mathrm{~nm}$ on the reduction of $\mathrm{NAD}^{+}$to NADH was measured spectrophotometrically. The reaction mixture contained $26 \mathrm{mmol} / \mathrm{L}$ glucose-6phosphate, $2.0 \mathrm{mmol} / \mathrm{L}$ EDTA, $2.0 \mathrm{mmol} / \mathrm{L} \mathrm{NAD}^{+}, 0.5$ $\mathrm{U} / \mathrm{mL}$ mutarotase, $5 \mathrm{U} / \mathrm{mL}$ glucose dehydrogenase, and 100 $\mathrm{mmol} / \mathrm{L}$ imidazole- $\mathrm{HCl}$. The reaction was initiated with the addition of $50 \mu \mathrm{L}$ liver enzyme preparation. The mixture was incubated for $2 \mathrm{~min}$, and the changes in absorbance of $\mathrm{NADH}$ production at $340 \mathrm{~nm}$ were then monitored for 5 min. An extinction coefficient of $6.22 \times 10^{3}(\mathrm{~mol} / \mathrm{L})^{-1} \cdot \mathrm{cm}^{-1}$ was used in calculating glucose-6-phosphate concentrations. The G6Pase activity was expressed as the amount of enzyme that catalyzed the hydrolysis of $1 \mu \mathrm{mol}$ of glucose-6-phosphate per minute per gram of wet liver under the conditions described above ${ }^{[23,24]}$.

\section{Determination of GP activity}

Total GP activity, which includes a and b forms of the enzyme, was also determined using a G6PD-coupled reaction ${ }^{[20,21,25]}$. The assay measures the formation of NADH during the GP-limited conversion of glycogen to glucose-1phosphate, which is converted first to glucose-6-phosphate and then to $\beta$ - $D$-gluconolactone by phosphoglucomutase and G6PD, respectively. The reaction mixture contained 1 $\mathrm{mg} / \mathrm{mL}$ glycogen, $1 \mathrm{U} / \mathrm{mL}$ phosphoglucomutase, $3 \mathrm{U} / \mathrm{mL}$ G6PD, $100 \mathrm{mmol} / \mathrm{L}$ potassium phosphate, $1 \mathrm{mmol} / \mathrm{L}$ AMP, $10 \mathrm{mmol} / \mathrm{L} \mathrm{MgCl}_{2}$ and $5 \mathrm{mmol} / \mathrm{L} \mathrm{NAD}^{+}$. The reaction was initiated with the addition of $50 \mu \mathrm{L}$ liver enzyme preparation, and the mixture was incubated for $2 \mathrm{~min}$. The changes of absorbance at $340 \mathrm{~nm}$ were monitored for $7 \mathrm{~min}$. GP activity was calculated as described above for the G6Pase assay ${ }^{[26]}$.

\section{RNA isolation and cDNA synthesis}

Frozen specimens (about $50 \mathrm{mg}$ ) were homogenized and the total RNA was extracted using TRIzol reagent according to the manufacturer's instructions. Total RNA was used for cDNA synthesis with M-MLV reverse transcriptase and
oligo-dT primers (Sangon, Shanghai, China) in a volume of $20 \mu \mathrm{L}$ at $37^{\circ} \mathrm{C}$ for $60 \mathrm{~min}$ and at $95^{\circ} \mathrm{C}$ for $5 \mathrm{~min}$.

\section{Real-time PCR quantification}

Primers were designed using the Primer Express oligo design software (Applied BioSystems, CA, USA) and synthesized by Invitrogen (Carlsbad, CA, USA). All primer sets were subjected to rigorous database searches to identify potential conflicting transcript matches to pseudo genes or homologous domains within related genes. The sequences of the real-time PCR primers for GAPDH, GP and G6Pasealpha cDNA are listed in Table 1. The SYBR Green I assay was used to detect products from the reverse-transcribed cDNA samples. GAPDH was used as the normalizer. PCR reactions for each sample were performed in duplicate, and the relative gene expressions were analyzed as previously described ${ }^{[27]}$.

Table 1. PCR primer pairs used amplify GAPDH, G6Pase, and GP cDNA fragments.

\begin{tabular}{lllccc}
\hline Target & & Oligonucleotide sequence & Tm $\left({ }^{\circ} \mathrm{C}\right)$ & bp \\
\hline GAPDH & F & 5' AAGAAGGTGGTGAAGCAGGC 3' & 59 & 203 \\
& R & 5' TCCACCACCCTGTTCTGTA 3' & & \\
GP & F & 5' GTGGTCCTGGCTCTGCCTAC 3' & 59 & 69 \\
& R & 5' GCGCATAGTGTCACAGTGTTG 3' & & \\
G6Pase & F & 5' AACGCCTTCTATGTCCTCTTC 3' & 59 & 168 \\
& R & 5' GTGCTGTAGTAGTCGGTGTCC 3' & & \\
& &
\end{tabular}

F, forward primer; Tm, melting temperature; $\mathrm{R}$, reverse primer.

\section{Western blot analysis}

Liver tissue homogenates in ice-cold mild lysis buffer were centrifuged at $14000 \times g, 4{ }^{\circ} \mathrm{C}$, for $15 \mathrm{~min}$ and supernatants were collected. Protein concentrations in the supernatants were measured using the BCA protein assay kit (Kangchen Bio-tech Inc, Shanghai, China). Then, $50 \mu \mathrm{g}$ protein samples were separated on $10 \%$ resolving $/ 4 \%$ stacking Tris- $\mathrm{HCl}$ gels. Separated proteins were transferred to polyvinylidene difluoride membranes. The membranes were blocked in 5\% BSA in $1 \times$ Tris buffered saline, $0.1 \%$ Tween-20 (TBST) for $1 \mathrm{~h}$ at room temperature. Blocked membranes were incubated with a rabbit polyclonal anti-G6Pase antibody or a rabbit polyclonal anti-GP antibody overnight at $4{ }^{\circ} \mathrm{C}$. The membranes were then washed and probed with a horseradish peroxidase-conjugated secondary antibody for $1 \mathrm{~h}$ at room temperature. Chemiluminescence detection was performed with the chemiluminescence detection kit (Kangchen Bio-tech Inc, China) according to the manufac- 
turer's instructions.

\section{Statistical analysis}

All data are expressed as means \pm SD. Continuous variables between groups at each time point were compared using one-way ANOVA, followed by the Student-NewmanKeuls procedure or Dunnett's T3 procedure when the assumption of equal variances did not hold. Two-tailed $P$ values $<0.05$ were considered statistically significant. Statistical analysis was conducted with SPSS 13.0.

\section{Results}

Effects of geniposide on plasma glucose, body weight, TC, TG and insulin levels

All control mice gained body weight throughout the 2 weeks of study, with increases of about $3.5 \mathrm{~g}$ over their pre-treatment body weight. No significant variance in blood glucose was observed in the normal control group (Table 2). HFD and STZ treatment significantly increased body weight, blood glucose, insulin and TG, but not TC levels compared with the normal control group. Administration of geniposide at a dose of $100 \mathrm{mg} / \mathrm{kg}$ for 2 weeks had little effect on the above parameters $(P>0.05)$. However, when the dose of geniposide increased to 200 $\mathrm{mg} / \mathrm{kg}$ and $400 \mathrm{mg} / \mathrm{kg}$, a significant decrease in body weight, blood glucose, insulin and TG levels was achieved, but there were no significant changes in TC compared with the diabetic control groups at the end of the experiment $(P>0.05$, Table 2).

\section{Effects of geniposide on GP and G6Pase activities}

As shown in Table 3, the activities of GP and G6Pase were significantly increased in HFD-STZ diabetic mice compared with normal control animals $(P<0.05)$. Geniposide at a dose of $100 \mathrm{mg} / \mathrm{kg}$ did not change the activities of either enzyme. When the doses of geniposide were increased to
Table 3. Effects of geniposide on GP and G6Pase activities. $n=10$. Mean \pm SD. ${ }^{\text {b } P<0.05 ~ v s ~ c o n t r o l ~ g r o u p s . ~}{ }^{\mathrm{e}} \mathrm{P}<0.05$ vs HFD-STZ diabetes mice.

\begin{tabular}{|c|c|c|}
\hline & $\begin{array}{c}\text { Glucose-6- } \\
\text { phosphatase } \\
\left(\mu \mathrm{mol} \cdot \mathrm{min}^{-1} \cdot \mathrm{g}^{-1} \text { liver }\right)\end{array}$ & $\begin{array}{c}\text { Glycogen } \\
\text { phosphorylase } \\
\mathrm{mol} \cdot \mathrm{min}^{-1} \cdot \mathrm{g}^{-1} \text { liver) }\end{array}$ \\
\hline Control groups & $58.52 \pm 9.65$ & $7.70 \pm 1.94$ \\
\hline STZ+HFD & $110.66 \pm 8.55^{\mathrm{b}}$ & $14.87 \pm 2.23^{\mathrm{b}}$ \\
\hline \multicolumn{3}{|l|}{ STZ+HFD+Geniposide } \\
\hline Geniposide 100 mg/kg & $106.59 \pm 9.00^{\mathrm{b}}$ & $13.49 \pm 2.44^{\mathrm{b}}$ \\
\hline Geniposide 200 mg/kg & $91.29 \pm 8.34^{\text {be }}$ & $11.32 \pm 1.38^{\text {be }}$ \\
\hline Geniposide 400 mg/kg & $70.24 \pm 6.51^{\text {be }}$ & $9.05 \pm 1.42^{\mathrm{e}}$ \\
\hline
\end{tabular}

$200 \mathrm{mg} / \mathrm{kg}$ and $400 \mathrm{mg} / \mathrm{kg}$, the activities of both enzymes were significantly decreased in the drug-treated diabetic groups compared with the diabetic control group.

\section{Effects of geniposide on mRNA expression of GP and G6Pase}

The mRNA levels of the GP and G6Pase genes were determined using real-time RT-PCR. The mRNA signals were normalized to the GAPDH mRNA signals for each group. The GP and G6Pase mRNA levels were significantly increased in the HFD-STZ diabetic control group compared with the normal control group. Geniposide at doses of 200 $\mathrm{mg} / \mathrm{kg}$ and $400 \mathrm{mg} / \mathrm{kg}$ markedly reduced the mRNA expression of GP and G6Pase compared with HFD-STZ diabetic control mice (Figure 3).

\section{Effects of geniposide on protein expression of GP and G6Pase}

We further investigated the effect of geniposide on GP and G6Pase expression at protein levels. GAPDH was used as a normalizer. The GP and G6Pase protein levels were significantly increased in HFD-STZ diabetic control mice

Table 2. Effects of genipioside on body weight, blood glucose, insulin, triglyceride (TG), and total cholesterol (TC) levels. $n=10$. Mean \pm SD. ${ }^{\mathrm{b}} \mathrm{P}<0.05$ vs control groups; ${ }^{\mathrm{e}} \mathrm{P}<0.05$ vs HFD-STZ diabetic mice.

\begin{tabular}{|c|c|c|c|c|c|c|c|c|c|}
\hline & \multicolumn{3}{|c|}{ Body weight (g) } & \multicolumn{3}{|c|}{ Glucose $(\mathrm{mmol} / \mathrm{L})$} & \multirow{2}{*}{$\begin{array}{l}\text { Insulin } \\
(\mu \mathrm{U} / \mathrm{mL}) \\
2 \text { weeks }\end{array}$} & \multirow{2}{*}{$\begin{array}{c}\mathrm{TG} \\
(\mathrm{mg} / \mathrm{dL}) \\
2 \text { weeks }\end{array}$} & \multirow{2}{*}{$\begin{array}{c}\text { TC } \\
(\mathrm{mg} / \mathrm{dL}) \\
2 \text { weeks }\end{array}$} \\
\hline & Pre-treatment & 1 week & 2 weeks & Pre-treatment & 1 week & 2 weeks & & & \\
\hline Control groups & $21.8 \pm 0.9$ & $23.4 \pm 0.7$ & $2+0$ & $6.06 \pm 0.43$ & $6.07 \pm$ & 5.9 & 0.36 & 115. & 108. \\
\hline $\mathrm{HFD}+\mathrm{STZ}$ & $28.2 \pm 0.8^{\mathrm{b}}$ & $28.6 \pm 0.7^{\mathrm{b}}$ & $28.0 \pm 1.0^{\mathrm{b}}$ & $21.06 \pm 1.48^{\mathrm{b}}$ & $19.20 \pm 2.05^{\mathrm{b}}$ & $19.08 \pm 1.20^{\mathrm{b}}$ & $0.70 \pm 0.08^{\mathrm{b}}$ & $164.6 \pm 12.3^{\mathrm{b}}$ & $115.3 \pm 13.9$ \\
\hline \multicolumn{10}{|c|}{ HFD+STZ+Geniposide } \\
\hline $100 \mathrm{mg} / \mathrm{kg}$ & $28.0 \pm 1.2^{\mathrm{b}}$ & $27.3 \pm 0.8^{b}$ & $27.2 \pm 0.8^{\mathrm{b}}$ & $20.08 \pm 2.41^{\mathrm{b}}$ & $17.39 \pm 1.20^{\mathrm{b}}$ & $17.08 \pm 1.64^{\mathrm{b}}$ & $0.64 \pm 0.08^{b}$ & $161.7 \pm 14.7^{\mathrm{b}}$ & $110.3 \pm 7.5$ \\
\hline $200 \mathrm{mg} / \mathrm{kg}$ & $28.1 \pm 1.2^{\mathrm{b}}$ & $27.2 \pm 0.4^{\mathrm{b}}$ & $26.7 \pm 0.8^{\text {be }}$ & $21.25 \pm 1.15^{\mathrm{b}}$ & $15.67 \pm 1.24^{\text {be }}$ & $11.92 \pm 1.27^{\text {be }}$ & $0.50 \pm 0.06^{\text {be }}$ & $131.3 \pm 11.5^{\text {be }}$ & $108.0 \pm 9.3$ \\
\hline $400 \mathrm{mg} / \mathrm{kg}$ & $28.2 \pm 1.0^{\mathrm{b}}$ & $26.8 \pm 1.1^{\text {be }}$ & $26.1 \pm 1.1^{\text {be }}$ & $21.16 \pm 2.28^{\mathrm{b}}$ & $12.74 \pm 1.20^{\text {be }}$ & $10.39 \pm 0.91^{\text {be }}$ & $0.40 \pm 0.07^{\mathrm{e}}$ & $120.9 \pm 9.8^{\mathrm{e}}$ & $104.4 \pm 9.8$ \\
\hline
\end{tabular}



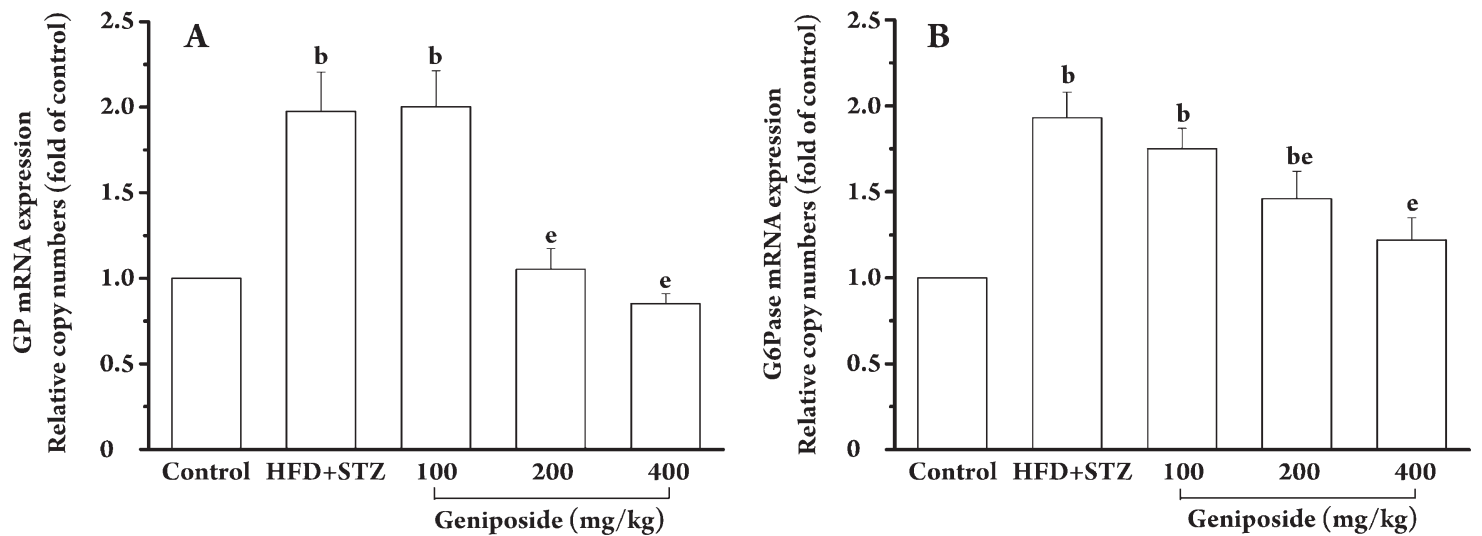

Figure 3. Effects of genipioside on mRNA expression of hepatic GP and G6Pase. HFD-STZ diabetic mice were treated with or without an indicated dose of geniposide for 2 weeks. The mRNA expression of hepatic GP (A) and G6Pase (B) was analyzed by real-time RT-PCR. ${ }^{\mathrm{b}} \mathrm{P}<0.05$ vs control groups. ${ }^{\mathrm{e}} \mathrm{P}<0.05$ vs HFD-STZ diabetic mice without geniposide treatment.

compared with the normal control animals. Geniposide at a dose of $200 \mathrm{mg} / \mathrm{kg}$ and $400 \mathrm{mg} / \mathrm{kg}$ for 2 weeks significantly decreased the protein expression of both enzymes compared with HFD-STZ diabetic control mice (Figure 4).

\section{Discussion}

The present study demonstrated that continuous treatment with geniposide for 2 weeks produced a significant decrease in blood glucose, insulin and TG levels and inhib- ited enzyme activities, as well as gene and protein expression of hepatic GP and G6Pase (the two glucose-metabolizing enzymes) in HFD-STZ-induced diabetic mice. To our knowledge, this is the first observation of the effects of geniposide on hepatic glucose-regulating enzymes.

C57B2/6J mice induced with diabetes by HFD-STZ have been widely used to study the effects of new drugs as treatment for type 2 diabetes ${ }^{[28,29]}$. The HFD-STZ diabetic mouse model established in our studies was consistent with that of previous studies ${ }^{[18]}$. In the 6 weeks after treatment
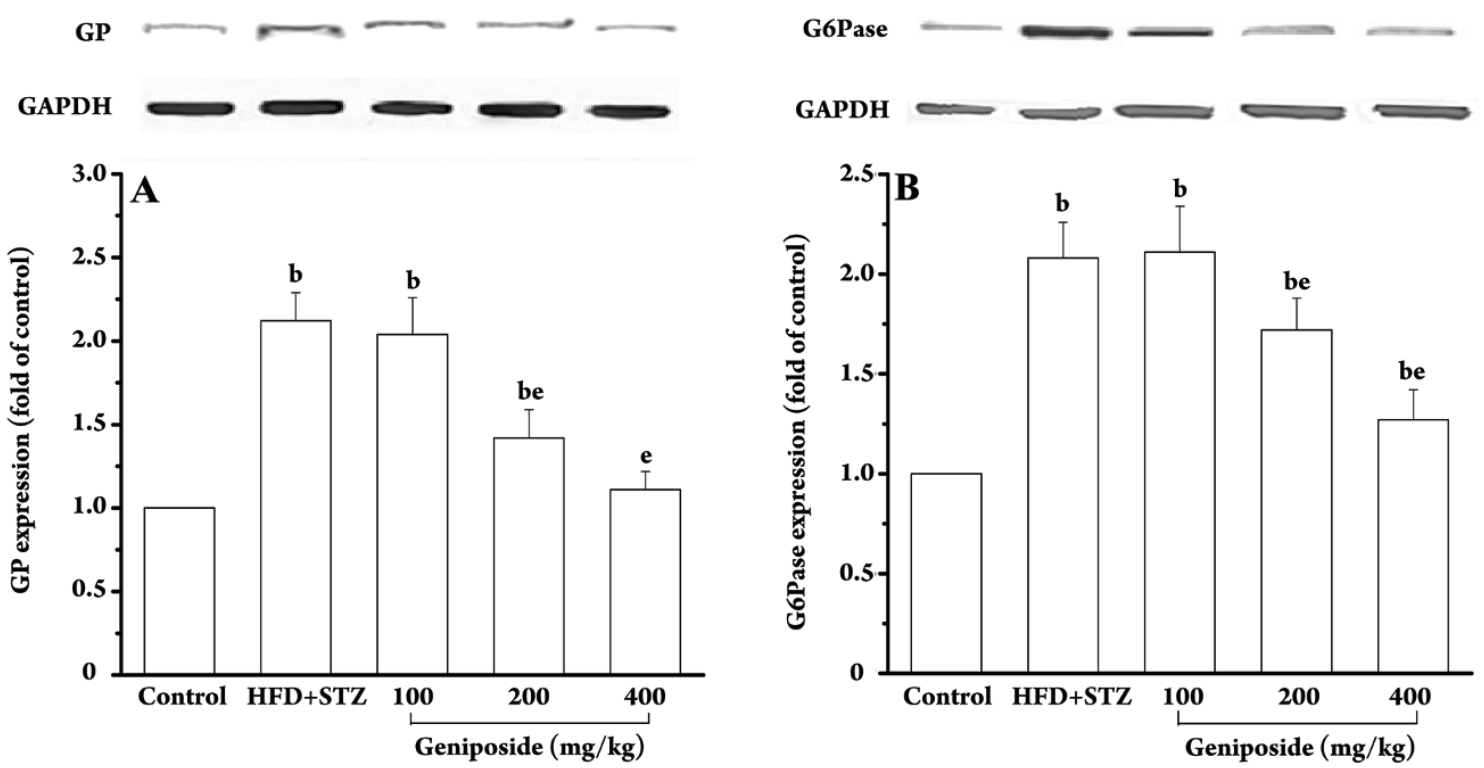

Figure 4. Effects of geniposide on protein expression of GP and G6Pase. HFD-STZ diabetic mice were treated with or without an indicated dose of geniposide for 2 weeks. The protein expression of hepatic GP (A) and G6Pase (B) was analyzed by Western blotting. ${ }^{b} P<0.05$ vs control groups. ${ }^{\mathrm{e}} \mathrm{P}<0.05$ vs HFD-STZ diabetic mice. 
with HFD-STZ, the mice developed type-2 diabetes-like symptoms such as hyperglycemia, hyperinsulinemia and body weight increase. The animals treated with geniposide for 2 weeks showed significant improvements in the signs of type 2 diabetes, including decreased body weight, as well as lowered blood glucose and serum insulin levels. These results further support geniposide as an effective hypoglycemic agent. It is important to note that the plasma insulin levels were reduced by geniposide treatment, which is consistent with previous studies ${ }^{[10]}$. However, further studies are needed to confirm whether insulin sensitivity has been restored by geniposide. For example, the downstream molecules of insulin signaling, such as protein kinase $\mathrm{B}$ (PKB/ Akt) and insulin receptors, which are characteristic of insulin resistance of type 2 diabetes, should be investigated ${ }^{[30]}$.

Chronic hyperglycemia in diabetes leads to changes in the expression of genes involved in glucose metabolism ${ }^{[31,32]}$. For example, hyperglycemia induced the expression of GP and G6Pase in a diabetic model ${ }^{[24,26,33]}$. In our HFD-STZ diabetic mice, we also observed a significant elevation of GP and G6Pase activities, as well as their mRNA and protein expression. The increased enzyme activities, in turn, led to a further increase in hepatic glucose production and aggravated the glucose metabolic imbalance ${ }^{[34,35]}$.

Our studies showed that the hypoglycemic effect of geniposide was mediated by the hepatic glucose regulation enzymes, GP and G6Pase. As compared with untreated HFD-STZ diabetic mice, geniposide induced a significant decrease in hepatic GP and G6Pase activities, as well as their gene and protein expression, resulting in inhibition of glycogenolysis and hepatic glucose production. Thus, it is reasonable to assume that regulation of hepatic GP and G6Pase by geniposide is important for lowering blood glucose levels in diabetic mice. The simultaneous inhibition of the two enzymes may have a complementary role in the geniposidemediated reduction of blood glucose levels.

A clear understanding of the molecular mechanisms of action of geniposide is important in the evaluation of this compound as a potential therapeutic agent. In the current study, although we revealed that geniposide decreased the expression of GP and G6Pase at mRNA and protein levels as well as enzyme activities, we were not able to determine whether geniposide itself had a direct effect on both enzymes. Previous studies have shown that genipin, the aglycone of geniposide, inhibits UCP2-mediated super oxide-dependent proton leak and reverses obesity and high glucoseinduced $\beta$ cell dysfunction in isolated pancreatic islet cells ${ }^{[16]}$. The activation of nuclear factor-kappa B (NF-kB) in cultured mouse macrophage-like cells was also suppressed by genipin administration ${ }^{[36]}$. More importantly, geniposide was shown to reduce the lipid peroxide (LPO) level in high sugar diet fed rats. Therefore, in order to understand the molecular mechanisms of geniposide for the treatment of type 2 diabetes, it is crucial to investigate the effects of geniposide on the pathways that involve oxidative stress and NF- $\mathrm{kB}$, which can ultimately lead to both the onset and the subsequent complication of diabetes mellitus ${ }^{[30]}$.

In conclusion, the present studies showed that geniposide was an effective hypoglycemic agent in HFD-STZ-induced diabetic mice. The geniposide-induced hypoglycemic effect is mediated, at least in part, by inhibiting GP and G6Pase activities. Geniposide may have potential in the treatment of type-2 diabetes.

\section{Acknowledgement}

This work was supported by the Science and Technology Bureau of Guangzhou (2006Z1-E6021).

\section{Author contribution}

Shao-yu WU, Guang-fa WANG, Jia-jie ZHANG, Shuguang WU, Zhong-qiu LIU and Jin-jun RAO designed the research; Shao-yu WU and Guang-fa WANG performed the research and analyzed the data; Lin LÜ and Wei XU contributed new analytical reagents and tools; Shao-yu WU, Guang-fa WANG, Jia-jie ZHANG and Shu-guang WU wrote the paper.

\section{References}

1 Barf T. Intervention of hepatic glucose production. Small molecule regulators of potential targets for type 2 diabetes therapy. Mini Rev Med Chem 2004; 4: 897-908.

2 Taguchi T, Yamashita E, Mizutani T, Nakajima H, Yabuuchi M, Asano $\mathrm{N}$, et al. Hepatic glycogen breakdown is implicated in the maintenance of plasma mannose concentration. Am J Physiol Endocrinol Metab 2005; 288: E534-40.

3 Jung UJ, Lee MK, Park YB, Kang MA, Choi MS. Effect of citrus flavonoids on lipid metabolism and glucose-regulating enzyme mRNA levels in type- 2 diabetic mice. Int J Biochem Cell Biol 2006; 38: 1134-45.

4 Jung UJ, Lee MK, Jeong KS, Choi MS. The hypoglycemic effects of hesperidin and naringin are partly mediated by hepatic glucoseregulating enzymes in c57bl/ksj-db/db mice. J Nutr 2004; 134 : 2499-503.

5 Agius L. New hepatic targets for glycaemic control in diabetes. Best Pract Res Clin Endocrinol Metab 2007; 21: 587-605.

6 Onda K, Suzuki T, Shiraki R, Yonetoku Y, Negoro K, Momose $\mathrm{K}$, et al. Synthesis of 5-chloro- $n$-aryl-1h-indole-2-carboxamide derivatives as inhibitors of human liver glycogen phosphorylase a. 
Bioorg Med Chem 2008; 16: 5452-64.

7 Kurukulasuriya R, Link JT, Madar DJ, Pei Z, Richards SJ, Rohde JJ, et al. Potential drug targets and progress towards pharmacologic inhibition of hepatic glucose production. Curr Med Chem 2003; 10: $123-53$.

8 McCormack JG, Westergaard N, Kristiansen M, Brand CL, Lau J. Pharmacological approaches to inhibit endogenous glucose production as a means of anti-diabetic therapy. Curr Pharm Des 2001; 7: 1451-74.

9 Miyasita S. A historical study of Chinese drugs for the treatment of jaundice. Am J Chin Med (Gard City NY) 1976; 4: 239-43.

10 Kimura Y, Okuda H, Arichi S. Effects of geniposide isolated from gardenia jasminoides on metabolic alterations in high sugar dietfed rats. Chem Pharm Bull (Tokyo) 1982; 30: 4444-7.

11 Koo HJ, Song YS, Kim HJ, Lee YH, Hong SM, Kim SJ, et al. Antiinflammatory effects of genipin, an active principle of gardenia. Eur J Pharmacol 2004; 495: 201-8.

12 Kuo WH, Wang CJ, Young SC, Sun YC, Chen YJ, Chou FP. Differential induction of the expression of gst subunits by geniposide in rat hepatocytes. Pharmacology 2004; 70: 15-22.

13 Pham TQ, Cormier F, Farnworth E, Tong VH, Van Calsteren MR. Antioxidant properties of crocin from gardenia jasminoides ellis and study of the reactions of crocin with linoleic acid and crocin with oxygen. J Agric Food Chem 2000; 48: 1455-61.

14 Park EH, Joo MH, Kim SH, Lim CJ. Antiangiogenic activity of gardenia jasminoides. Fruit Phytother Res 2003; 17: 961-2.

15 Yan JE, Li WC, Bian GX, Wen LQ, Ren JP. Effect of geniposide on blood sugar reduction and its activation to PPAR $\gamma$ receptor. J Sichuan Agric Univ 2007; 25: 415-8.

16 Zhang CY, Parton LE, Ye CP, Krauss S, Shen R, Lin CT, et al. Genipin inhibits ucp2-mediated proton leak and acutely reverses obesity- and high glucose-induced beta cell dysfunction in isolated pancreatic islets. Cell Metab 2006; 3: 417-27.

17 Report of the American Institute of Nutrition Ad Hoc Committee on Standards for Nutritional Studies. J Nutr 1977; 107: 1340-8.

18 Luo J, Quan J, Tsai J, Hobensack CK, Sullivan C, Hector R, et al. Nongenetic mouse models of non-insulin-dependent diabetes mellitus. Metabolism 1998; 47: 663-8.

19 Wallis MG, Appleby GJ, Youd JM, Clark MG, Penschow JD. Reduced glycogen phosphorylase activity in denervated hindlimb muscles of rat is related to muscle atrophy and fibre type. Life Sci 1999; 64: 221-8.

20 Nordlie RC, Arion WJ. Liver microsomal glucose 6-phosphatase, inorganic pyrophosphatase, and pyrophosphate-glucose phosphotransferase. 3. Associated nucleoside triphosphate- and nucleoside diphosphate-glucose phosphotransferase activities. J Biol Chem 1965; 240: 2155-64.

21 Nordlie RC, Arion WJ. Glucose-6-Phosphatase. Methods Enzymol 1966; 9: 619-25.
22 Nordlie RC, Arion WJ, Glende EA Jr. Liver microsomal glucose 6-phosphatase, inorganic pyrophosphatase, and pyrophosphateglucose phosphotransferase. iv. effects of adrenalectomy and cortisone administration on activities assayed in the absence and presence of deoxycholate. J Biol Chem 1965; 240: 3479-84.

$23 \mathrm{Yu} \mathrm{K,} \mathrm{Schomisch} \mathrm{SJ,} \mathrm{Chandramouli} \mathrm{V,} \mathrm{Lee} \mathrm{Z.} \mathrm{Hexokinase} \mathrm{and}$ glucose-6-phosphatase activity in woodchuck model of hepatitis virus-induced hepatocellular carcinoma. Comp Biochem Physiol C Toxicol Pharmacol 2006; 143: 225-31.

24 Alegre M, Ciudad CJ, Fillat C, Guinovart JJ. Determination of glucose-6-phosphatase activity using the glucose dehydrogenasecoupled reaction. Anal Biochem 1988; 173: 185-9.

25 Lowry OH, Schulz DW, Passonneau JV. The kinetics of glycogen phosphorylases from brain and muscle. J Biol Chem 1967; 242: 271-80.

26 Freeman S, Bartlett JB, Convey G, Hardern I, Teague JL, Loxham SJ, et al. Sensitivity of glycogen phosphorylase isoforms to indole site inhibitors is markedly dependent on the activation state of the enzyme. Br J Pharmacol 2006; 149: 775-85.

27 Livak KJ, Schmittgen TD. Analysis of relative gene expression data using real-time quantitative PCR and the $2^{-\Delta \Delta C T}$ method. Methods 2001; 25: 402-8.

28 Reed MJ, Scribner KA. In-vivo and in-vitro models of type 2 diabetes in pharmaceutical drug discovery. Diabetes Obes Metab 1999; $1: 75-86$

29 Chen D, Wang MW. Development and application of rodent models for type 2 diabetes. Diabetes Obes Metab 2005; 7: 30717.

30 Maiese K, Chong ZZ, Shang YC. Mechanistic insights into diabetes mellitus and oxidative stress. Curr Med Chem 2007; 14: 1729-38.

31 Nordlie RC, Foster JD, Lange AJ. Regulation of glucose production by the liver. Annu Rev Nutr 1999; 19: 379-406.

32 Bollen M, Keppens S, Stalmans W. Specific features of glycogen metabolism in the liver. Biochem J 1998; 336 (Pt 1): 19-31.

33 Nemeti B, Gregus Z. Glutathione-dependent reduction of arsenate by glycogen phosphorylase a reaction coupled to glycogenolysis. Toxicol Sci 2007; 100: 36-43.

34 Roden M, Perseghin G, Petersen KF, Hwang JH, Cline GW, Gerow $\mathrm{K}$, et al. The roles of insulin and glucagon in the regulation of hepatic glycogen synthesis and turnover in humans. J Clin Invest 1996; 97: 642-8.

35 Petersen KF, Laurent D, Rothman DL, Cline GW, Shulman GI. Mechanism by which glucose and insulin inhibit net hepatic glycogenolysis in humans. J Clin Invest 1998; 101: 1203-9.

36 Takeuchi S, Goto T, Mikami K, Miura K, Ohshima S, Yoneyama $\mathrm{K}$, et al. Mechanistic insights into diabetes mellitus and oxidative stress. Hepatol Res 2005; 33: 298-305. 